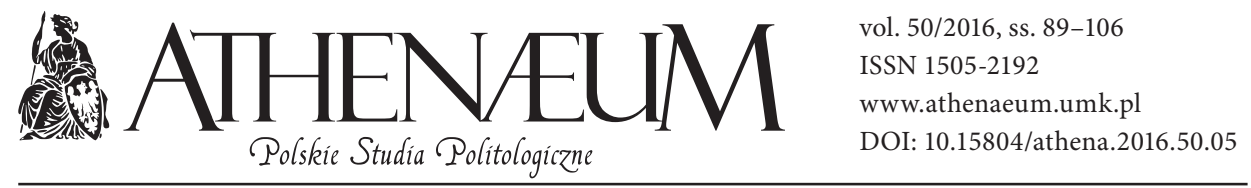

\title{
KILKA UWAG O EUROPEJSKIM BEZPIECZEŃSTWIE W KONTEKŚCIE NAKŁADÓW PAŃSTW CZłONKOWSKICH UNII EUROPEJSKIEJ NA OBRONNOŚĆ
}

\author{
A FEW REMARKS ON EUROPEAN SECURITY IN THE CONTEXT \\ OF THE EU MEMBER STATES' DEFENCE EXPENDITURES
}

Rafał Willa*

\begin{abstract}
ABSTRAKT
Bezpieczeństwo jest dziś słowem-kluczem. Bez jego zagwarantowania nie może być mowy o rozwoju społeczno-gospodarczym państw czy organizacji. Bez niego żaden podmiot nie będzie w stanie sprostać pojawiającym się co chwilę wyzwaniom. I choć świat ulega dynamicznym przeobrażeniom, to jednak wciąż w cenie jest posiadanie realnej siły i zdolności odstraszania potencjalnych nieprzyjaciół. Poprawne lub nawet świetne kontakty gospodarcze nie zastąpią więc sił zbrojnych, silnych przemysłów obronnych czy paktów militarnych. Dlatego państwa Starego Kontynentu, wszystkie bez wyjątku, zdać muszą sobie wreszcie sprawę, że trwające od lat redukowanie wydatków wojskowych i wykorzystywanie USA jako gwaranta europejskiego bezpieczeństwa musi się zakończyć. Czas, by Europa wzięła większą odpowiedzialność za siebie i świat. A potencjał ku temu jest wystarczający.
\end{abstract}

Słowa kluczowe: bezpieczeństwo, zdolności obronne, przemysł obronny, wydatki na obronność, Europa
Security has become the key word nowadays. Without the guarantee of security there is no social or economic development of countries or organisations. Without it no subject will be able to face ongoing challenges. Even though the world is evolving dynamically, it is still essential to have real power and the ability to deter potential enemies. Satisfactory or even excellent economic relations will not replace military power, strong defense industries or military pacts. Therefore, the countries of the Old Continent, without exceptions, must finally realise the fact that decrease in military expanses and treating the USA as a guarantee of European security must come to an end. It is high time Europe took greater responsibility for itself and the world. The potential to achieve this goal is big enough.

Keywords: security, military capabilities, military industry, defence expenditures, Europe

* Uniwersytet Mikołaja Kopernika w Toruniu, Wydział Politologii i Studiów Międzynarodowych. 
Od wielu już lat potencjał wojskowy Unii Europejskiej i idąca w ślad za nim idea wspólnej polityki obronnej jest przedmiotem żywego zainteresowania analityków stosunków międzynarodowych. W tym kontekście warto tutaj wspomnieć również o jednej z niedawnych wypowiedzi Przewodniczącego Komisji Europejskiej Jean-Claude’a Juncker'a, który w jednym z wywiadów opowiedział się za utworzeniem wspólnej armii europejskiej. Tym samym podsycił on toczącą się debatę o przyszłej roli UE w stosunkach międzynarodowych i zapewnianiu globalnego bezpieczeństwa (Frontini, 2015). Niemniej jednak wskazać przyjdzie, że opinie w tej materii są niezwykle zróżnicowane: od entuzjazmu, że militaryzacja UE będzie zwieńczeniem procesów integracji Europejskiej (Howorth, 2000), przez poglądy umiarkowane, że owszem UE zyska w ten sposób wojskowy wymiar współpracy, lecz utraci zarazem wizerunek mocarstwa cywilnego (Smith, 2000), do krytycznych, które dowodzą, że takie działania oznaczają regres w procesach integracyjnych i postrzeganiu UE na świecie (Manners, 2006).

Nie da się też ukryć, że przez kilkadziesiąt bez mała lat Europa Zachodnia, a teraz UE licząca już 28 członków, korzystała $z$ „parasola ochronnego” Stanów Zjednoczonych. Państwa europejskie wykorzystywały, by nie rzec - nadużywały stałą obecność wojsk USA na Starym Kontynencie, także do tego, by móc ograniczać ponoszone nakłady na własną obronność i w ten sposób redukować deficyty budżetowe. Kongres USA stworzył nawet termin ,jazdy na gapę, jakże dla Europy pogardliwy, niemniej nie pozbawiony podstaw. Kryzys finansowy lat 2008-2010 tylko pogłębił i utrwalił te tendencje. USA zaś, widząc, że centrum wydarzeń globalnych przenosi się z obszaru euroatlantyckiego do Azji, tam też kieruje obecnie coraz większą swą uwagę. Dyplomaci amerykańscy od lat nalegają również na powstrzymanie cięć budżetowych w sektorze obronnym państw europejskich, tym samym starając się zachęcić Europę do wzięcia większej odpowiedzialności za swoje, i nie tylko, bezpieczeństwo (Barcikowska, 2013).

\section{POTENCJAŁ WOJSKOWY UNIJNEJ EUROPY}

Stany Zjednoczone od lat krytykowały Europę, nie całą oczywiście, za poszukiwanie oszczędności budżetowych w sektorze obronności, za przyjmowanie założenia, że można więcej za mniej... Najnowsze dane Sojuszu Północnoatlantyckiego są w tym względzie bardzo niewygodne dla jego europejskiej flanki. Dość bowiem powiedzieć, że o ile USA $(50,4 \%)$ i Europa (liczona razem 
$\mathrm{z}$ Kanadą $=49,6 \%)$ mają porównywalny PKB w ramach Paktu, to jednak na Stany Zjednoczone przypada aż 72,2\% skumulowanych wydatków na obronność całego Sojuszu. Proporcje te więc są mocno zaburzone, wstydliwe dla Europy i irytujące dla przyjaciół zza oceanu. Choć więc te dane nie do końca są porównywalne, to jednak świadczą o tym, że problem jest i należy poczynić znaczne wysiłki mające na celu lepsze zbilansowanie potencjałów wszystkich partnerów w ramach Sojuszu (NATO, 2016).

Jak stwierdził Andrzej Gałganek (2011), „,w stosunkach międzynarodowych technologia jest jednym z najważniejszych czynników wpływających na ich przebieg. W wielkich historycznych narracjach technologia, a szczególnie technologia militarna, zajmuje często centralne miejsce" (s. 19). Stąd przyjrzeć się wypada potencjałowi, jakim dysponują państwa członkowskie Unii Europejskiej w zakresie wojskowości. Jak przedstawia się więc skumulowany potencjał militarny państw Unii Europejskiej? Jak wypada on na tle głównego sojusznika i jedynego obecnie mocarstwa światowego, czyli Stanów Zjednoczonych? Wreszcie jakie wskaźniki mają tu szczególne znaczenie? Wydaje się, iż kluczowe znaczenie będą mieć tutaj takie czynniki, jak liczebność wojsk, ich mobilność, nakłady na obronność, nakłady per capita, rozwój przemysłu zbrojeniowego czy inwestycje BRT (EAO, 2012). Nie wiedzieć jednak czemu ostatnie tego typu opracowanie autorstwa Europejskiej Agencji Obrony zawiera dane z 2011, a więc dość stare, niemniej jednak dobitnie ukazujące różnice finansowe i potencjałów dzielące atlantyckich sojuszników.

Jeżeli chodzi o liczebność personelu wojskowego, to sumarycznie państwa UE $(1,5 \mathrm{mln})$ wypadają lepiej aniżeli USA $(1,4 \mathrm{mln})$. Porównanie liczby personelu cywilnego pracującego dla wojska wypada korzystniej dla USA, które zatrudniają ponad 800 tys. ludzi, a państwa UE nieco ponad 370 tys. Zauważalny jest jednak spadek liczby personelu wojskowego i cywilnego w państwach UE, natomiast USA w obu tych kategoriach wskaźniki mają, generalnie, tendencję wzrostową. Teoretycznie więc Europa nie ma czego się wstydzić w tym względzie, bowiem na tle swego sojusznika wypada dobrze, a liczniejszą armię posiadają zapewne tylko Chiny. Jednakże na współczesnym polu walki to nie liczba żołnierzy decyduje o wyniku starcia, lecz ich wyszkolenie, mobilność i uzbrojenie. W tej kwestii USA zdecydowanie przewyższają wszystkie państwa UE razem wzięte ${ }^{1}$.

1 Od czasu zakończenia II wojny światowej USA zredukowały personel wojskowy o ok. 35\% (Europa o ok. 40\%), pozostawiając na dotychczasowym poziomie (o ile nie większym) nakłady na sprzęt wojskowy, dzięki czemu ich armia stała się szczuplejsza, acz lepiej dopasowana do potrzeb 
Redukcja potencjału liczbowego w armiach państw UE wynika, w głównej mierze, $z$ chęci posiadania armii mniej licznej, za to zawodowej, lepiej wyszkolonej i zdolnej do szybkiego reagowania. Przynajmniej w teorii, oficjalnie; nieoficjalnie natomiast szuka się oszczędności. Zaobserwować można również stopniowe odchodzenie od poboru, m.in. w Polsce, lecz proces ten w Europie przebiega bardzo wolno. Powoduje to, w konsekwencji, że liczebność armii państw UE jest nadal nieproporcjonalnie duża, a przy tym są one mniej sprawne aniżeli armie zawodowe. Poborowi stanowią już jednak zdecydowaną mniejszość w siłach zbrojnych państw UE należących do NATO.

Gdy przyjrzeć się wydatkom ponoszonym na cele wojskowe, w tym utrzymanie armii, zakup nowego uzbrojenia czy badania nad nowymi technologiami wojskowymi, okaże się, że państwa UE pozostają bardzo daleko w tyle za Stanami Zjednoczonymi. Dość powiedzieć, że w 2011 roku USA wydały na obronność około 503 mld euro, a ich wszyscy europejscy sojusznicy „zaledwie” $193 \mathrm{mld}$ euro $^{2}$. Widać to również doskonale po porównaniu procentowych nakładów na obronność, bowiem USA wydały rocznie ponad 4,6\% swojego PKB na ten cel, zaś państwa UE średnio zaledwie 1,5\% PKB. Co więcej, w USA wydatki na obronność stanowiły ponad $11 \%$ wydatków rządowych, a po drugiej stronie Atlantyku niewiele ponad 3\%. Ze wskaźnikiem 1610 euro per capita są Stany Zjednoczone absolutnym światowym liderem wydatków na obronność, wyprzedzając państwa UE ponad czterokrotnie (niespełna 400 euro). Mając te liczby na uwadze, stwierdzić przyjdzie, iż nie ma obecnie szans na to, by państwa UE nadrabiały dzielący je dystans technologii obronnej w stosunku do USA. Więcej, ten dystans stale się powiększa, powodując tym samym jeszcze większe uzależnienie państw UE od „parasola ochronnego" USA.

Warto także zastanowić się, jak suche liczby budżetowe przekładają się na siłę i znaczenie pojedynczego żołnierza. USA wypadają w tym względzie, znów nie może być mowy o zaskoczeniu, dużo korzystniej. Wskaźnik ten wynosił bowiem ponad 350 tys. euro, podczas gdy w UE nieco ponad 124 tys. euro. Mając również na względzie skuteczność żołnierza na polu walki, ważnym wskaźnikiem są inwestycje BRT przypadające na pojedynczego żołnierza. USA zdystansowały

polityki zagranicznej państwa, bardziej elastyczna, mobilna i zdolna do przemieszczania w dowolny zakątek świata, czego nie da się powiedzieć o zasobach europejskich, z niewielkim wyjątkiem Francji i Wielkiej Brytanii (Huxham, Rempling, 2013).

2 Wskaźnik ten w Europie nadal maleje - w 2012 roku wyniósł już tylko 190 mld euro. Małym przełomem okazał się być dopiero rok 2015, z nakładami ok 200 mld euro. 
państwa Europy ponad czterokrotnie, $\mathrm{z}$ nakładami w wysokości ponad 100 tys. euro, a średnia europejska wyniosła skromne 24 tys. euro ${ }^{3}$.

Narastająca nierównowaga potencjałów militarnych państw członkowskich UE i USA wynika również z nieefektywnego sposobu funkcjonowania europejskiego przemysłu zbrojeniowego (AMCHAM; Bigo, Jeandesboz, 2010). Mimo swego znaczącego potencjału działania mające na celu jego synchronizację i koordynację nie przynoszą pożądanego efektu. Pojedyncze wspólne programy badawcze, wspólne projekty zbrojeniowe, ułatwienia w transferze nowoczesnych technologii czy koprodukcja są tylko wyjątkami potwierdzającymi regułę. A jest nią rozdrobnienie i rywalizacja między poszczególnymi państwami członkowskimi UE - przemysł zbrojeniowy ma bowiem olbrzymie znaczenie gospodarcze i polityczne, co praktycznie uniemożliwia objęcie go Jednolitym Rynkiem. Ważniejsze są partykularne interesy państw aniżeli możliwość przyczynienia się do wzmocnienia pozycji militarnej UE jako odrębnego bytu prawnomiędzynarodowego ${ }^{4}$.

Nie jest jednak wyłącznie tak, że europejskie koncerny zbrojeniowe przez swe rozdrobnienie czy protekcjonistyczne praktyki stosowane przez władze poszczególnych państw mają marginalne znaczenie w globalnym obrocie sprzętem wojskowym. Wręcz przeciwnie, mimo oczywistych trudności i problemów europejskiego rynku w ostatnich latach w pierwszej dziesiątce największych eksporterów broni na świecie znajduje się aż 6 państw członkowskich UE. Ranking największych firm zbrojeniowych świata także zdominowany jest przez firmy z obszaru euroatlantyckiego, a w pierwszej dziesiątce magazyn „Defence News" umieścił 3 koncerny z Europy i 7 z USA. Państwa i firmy europejskie mają bowiem tę przewagę nad rywalami z państw trzecich, że są w posiadaniu bogatej i zróżnicowanej listy produktów, dysponują wiedzą ekspercką, umiejętnościami poszukiwania nowych nisz na rynku, doświadczeniem we współpracy wielonarodowej czy potrafią kooperować z sektorem cywilnym (Wiśniewski, 2012).

3 W tych kategoriach w Europie wyróżniają się Francja, Wielka Brytania i Niemcy; klasę średnią zaś stanowią Włochy, Holandia, Polska, Hiszpania i Szwecja. W pozostałych państwach członkowskich UE przedstawiane wskaźniki są bardzo niewielkie (EAO, 2014b).

4 Podstawowymi czynnikami wpływającymi na obniżenie znaczenia Wspólnej Polityki Bezpieczeństwa i Obrony (WPBiO), oprócz braku woli politycznej, są: niewielka mobilność wojsk (zaledwie 10-15\% żołnierzy państw UE można szybko przerzucić w dowolny region świata), dublowanie struktur, nadal istniejący pobór do wojska, luki technologiczne (Margaras, 2010). 
Tabela 1. Porównanie nakładów na obronność UE i USA (2011 rok*)

\begin{tabular}{|c|c|c|c|c|c|c|}
\hline \multirow{2}{*}{$\begin{array}{l}\text { Wydatki na } \\
\text { obronność }\end{array}$} & \multicolumn{2}{|c|}{2010} & \multicolumn{2}{|c|}{2011} & \multicolumn{2}{|c|}{$\begin{array}{l}\text { Zmiana procentowa } \\
\text { w latach } 2010-2011\end{array}$} \\
\hline & UE & USA & UE & USA & UE & USA \\
\hline Jako \% PKB & $1,61 \%$ & $4,77 \%$ & $1,55 \%$ & $4,66 \%$ & $-3,4 \%$ & $-2,3 \%$ \\
\hline $\begin{array}{l}\text { Jako \% całkowi- } \\
\text { tych wydatków } \\
\text { budżetowych }\end{array}$ & $3,20 \%$ & $11,23 \%$ & $3,17 \%$ & $11,18 \%$ & $-0,9 \%$ & $-0,4 \%$ \\
\hline Per capita & 390 euro & 1676 euro & 387 euro & 1610 euro & $-0,7 \%$ & $-3,9$ \\
\hline ŁĄCZNIE & $\begin{array}{l}194 \text { mld } \\
\text { euro }\end{array}$ & $\begin{array}{l}520 \text { mld } \\
\text { euro }\end{array}$ & $\begin{array}{l}193 \text { mld } \\
\text { euro }\end{array}$ & $\begin{array}{l}503 \text { mld } \\
\text { euro }\end{array}$ & $-0,5 \%$ & $-3,3 \%$ \\
\hline \multirow{2}{*}{ Personel } & \multicolumn{2}{|c|}{2010} & \multicolumn{2}{|c|}{2011} & \multicolumn{2}{|c|}{ zmiana $2010-2011 \mathrm{w} \%$} \\
\hline & UE & USA & UE & USA & UE & USA \\
\hline Personel wojskowy & 1620188 & 1430985 & 1551038 & 1425113 & $-4,3 \%$ & $-0,4 \%$ \\
\hline Personel cywilny & 389719 & 777844 & 374427 & 807162 & $-3,9 \%$ & $3,8 \%$ \\
\hline $\begin{array}{l}\text { Wydatki na pojedyn- } \\
\text { czego żołnierza }\end{array}$ & $\begin{array}{c}119455 \\
\text { euro }\end{array}$ & $\begin{array}{c}363166 \\
\text { euro }\end{array}$ & $\begin{array}{c}124133 \\
\text { euro }\end{array}$ & $\begin{array}{c}352606 \\
\text { euro }\end{array}$ & $3,9 \%$ & $-2,9 \%$ \\
\hline $\begin{array}{c}\text { Inwestycje } \\
\text { w pojedynczego } \\
\text { żołnierza (zamówie- } \\
\text { nia na sprzęt oraz } \\
\text { badania i rozwój } \\
\text { technologiczny) }\end{array}$ & 26458 euro & $\begin{array}{c}110998 \\
\text { euro }\end{array}$ & $\begin{array}{c}23829 \\
\text { euro }\end{array}$ & $\begin{array}{c}102264 \\
\text { euro }\end{array}$ & $-9,9 \%$ & $-7,9 \%$ \\
\hline
\end{tabular}

* brak nowszych danych.

Źródło: Europejska Agencja Obrony. (2013). Europe and United States Defence Expenditures 2011, Bruksela, s. 4 i 13.

Kilka słów atencji poświęcić w tym miejscu wypada również kwestii różnych stanowisk państw członkowskich UE względem budowania militarnych zdolności organizacji. W większości państw unijnych nadal dominuje pogląd, iż militaryzacja organizacji nie spowoduje, $\mathrm{w}$ dającej się przewidzieć przyszłości, przekształcenia struktur europejskich w potęgę wojskową. Powyższe uwagi dobitnie świadczą również o tym, że jakiekolwiek porównania potencjału wojskowego UE (czy też nawet sumy potencjału państw członkowskich) z możliwościami Stanów Zjednoczonych są dla niej wielce niekorzystne. Wynika to z jednej strony z faktu, iż mamy do czynienia ze strukturą międzyrządową, pozbawioną statusu państwa czy choćby sojuszu wojskowego ani (jak się wydaje) niezmierzającą 
nawet $\mathrm{w}$ tę stronę. $\mathrm{Z}$ drugiej natomiast mamy państwo, mocarstwo, militarnie niemające żadnej konkurencji w historii świata.

Zasadne jest zatem tutaj pytanie o sens ewentualnego przekształcania UE w realną siłę militarną, która byłaby konkurencyjna wobec NATO i zdolna do samodzielnego działania. Wszak 22 państwa członkowskie UE należą również do NATO, a Traktat z Lizbony, gwoli przypomnienia, wyraźnie wskazuje, iż to Sojusz ma w kwestiach obronnych pierwszeństwo działania (art. 42 Traktatu o UE oraz Protokoły nr 10 i 11 dołączone do Traktatu o Funkcjonowaniu UE). Ponadto w czasach redukcji wydatków na obronność wiele państw $\mathrm{z}$ trudem radzi sobie z wypełnianiem swoich zobowiązań względem Sojuszu Północnoatlantyckiego, więc tym bardziej dodatkowe nakłady na tworzenie silnych i niezależnych struktur unijnych w tej materii nie znalazłyby uznania większości społeczeństw europejskich. Próżno również doszukiwać się zgodnego głosu liderów UE na arenie międzynarodowej. Dość powiedzieć, że „wielka trójka”, tj. Francja, Niemcy i Wielka Brytania, nie zajęły wspólnego stanowiska np. w kwestii interwencji w Iraku (2003), Libii (2011), Mali (2013) i ewentualnej interwencji w Syrii (2013). O wspólnym głosie nie może zatem być mowy.

Tabela 2. Stanowiska Francji, Wielkiej Brytanii i Niemiec w kwestii zbrojnego zaangażowania w konflikty na świecie

\begin{tabular}{|c|c|c|c|}
\hline Miejsce & Francja & Wielka Brytania & Niemcy \\
\hline Irak (2003) & Nie & Tak & Nie \\
\hline Libia (2011) & Tak & Tak & Nie \\
\hline Mali (2013) & Tak & Nie (wsparcie) & Nie \\
\hline $\begin{array}{c}\text { Syria (2013 - chęć podjęcia } \\
\text { interwencji) }\end{array}$ & Tak & Nie & Nie \\
\hline
\end{tabular}

Źródło: Faleg, G. (2013). The Governance Gap in European Security and Defence, CEPS Policy Brief, nr 310, s. 3.

\section{BUDOWANIE POTENCJAŁU OBRONNEGO PAŃSTW UNII EUROPEJSKIEJ - PRZYCZYNY TRUDNOŚCI}

Pośród głównych przyczyn utrzymującej się nieefektywności polityk obronnych państw Starego Kontynentu wskazać przyjdzie permanentny brak zaufania między krajami. Ileż to już razy zdarzało się, że państwa ustalały coś wspólnie, 
a potem kolejno wyłamywały się z podjętych ustaleń. Ileż to razy byliśmy świadkami konferencji, na których elity rządowe danego państwa coś obiecywały, by potem, po cichu i bez kamer, wycofywać się ze swych zapewnień. I to nie tylko w sferze obronności, gdzie wiele państw niemal otwarcie nie wywiązuje się ze swoich obowiązków względem UE czy NATO (np. poziom finansowania sektora obronnego), ale także wspólnego rynku, konkurencji czy innych dziedzin szczegółowych. A że obronność to sfera blisko powiązana z suwerennością i szczególnego zaufania społecznego, to i państwa bardzo niechętnie podejmują współpracę.

Tutaj rysuje się wyzwanie dla Europejskiej Agencji Obrony, która powinna bardziej zdecydowanie podjąć wyzwanie budowy platformy wzajemnego zaufania państw i późniejszego angażowania ich we wspólne projekty i programy militarne (Faleg, 2013). Jest to o tyle trudne, że zgodnie z art. 346 ust. 1 lit. b) Traktatu o Funkcjonowaniu UE „każde państwo członkowskie może podejmować środki, jakie uważa za konieczne w celu ochrony podstawowych interesów jego bezpieczeństwa, a które odnoszą się do produkcji lub handlu bronią, amunicją lub materiałami wojennymi [...]”. Stąd pozytywnie ocenić przyjdzie uruchomienie przez Agencję dwóch portali internetowych: w 2007 roku EDSIS (Europejski System Informacji o Normach Obronnych) oraz w 2011 roku EDSTAR (Europejska Baza Rekomendowanych Dokumentów Normalizacji Obronnej). To dobry punkt wyjścia do stwarzania możliwości współpracy państw unijnych (DeVore, Eisenecker, 2010).

Z pewnością rok 2008, a więc początek kryzysu finansowego, który tak mocno odcisnął swe piętno na państwach zwłaszcza tzw. „starej” UE, zmuszając je do dokonywania drastycznych oszczędności w wydatkach publicznych, przyczynił się do nie tyle nawet zahamowania, co cofnięcia postępów integracyjnych w sektorze obronnym i zaprzestania modernizacji sił zbrojnych. To rygory członkostwa w UE, dotyczące w szczególności długu publicznego czy deficytu budżetowego, a nie ponadprzeciętnie wysoki poziom społecznego poczucia bezpieczeństwa czy też pozytywne zmiany geopolityczne wokół granic zewnętrznych UE były czynnikami wyznaczającymi trendy budżetowe w państwach europejskich. Efekt finalny takich poczynań mógł być oczywiście, z grubsza, tylko jeden - mniej zakupów nowego uzbrojenia, redukcja liczebności armii, zmniejszenie zdolności i gotowości bojowej wojsk państw europejskich, zatrzymanie procesów modernizacyjnych i reform mających na celu uczynienie sił bardziej mobilnymi. W tym wszystkim, mimo wydarzeń na Ukrainie, w Północnej Afryce i na Bliskim Wschodzie kwestia dalszego rozwijania WPBiO UE została niemal całkowicie pominięta. A szkoda... 
Należy również podnieść fakt, iż państwa członkowskie UE mają zdecydowanie różne podejście do kwestii ponoszenia wydatków na obronność, a także co do sposobu wdrażania programów oszczędnościowych. Można rzec, że zintegrowana gospodarczo Europa jest w tej materii podzielona niemal na pół - są państwa, które rokrocznie starają się utrzymywać lub nieznacznie podnosić nakłady budżetowe na obronę, ale i występują takie, gdzie zaskakująco łatwo tnie się w budżecie wszelkie tego typu pozycje ${ }^{5}$. Taki obrót spraw powoduje oczywiste trudności primo w reformowaniu sił zbrojnych, secundo w przekształcaniu WPBiO w efektywne narzędzie polityki międzynarodowej, wreszcie tertio w sprawie, o czym była już mowa, podnoszenia poziomu wzajemnego zaufania między państwami członkowskimi UE. Na ten moment wygląda to bowiem tak, jakby część państw nie dostrzegała wokół siebie żadnych zagrożeń dla bezpieczeństwa, a jeśli nawet, to zdaje się liczyć na pomoc i wsparcie pozostałych członków UE czy NATO. Wszak tak łatwiej przypodobać się wielu wyborcom, jakże przyzwyczajonym do złudnego poczucia bezpieczeństwa... Jakby nie przyjmując do wiadomości, że działające samodzielnie państwa europejskie, nawet Francja czy Wielka Brytania, nie są już dłużej w stanie samodzielnie odgrywać roli mocarstw na arenie międzynarodowej (Barry, Binnendijk, 2012).

Tabela 3. Kluczowe informacje o kondycji sektora obronnego w państwach członkowskich UE*

\begin{tabular}{|c|c|c|c|c|}
\hline Państwo & $\begin{array}{c}\text { Wydatki na obron- } \\
\text { ność - zmiana } \\
\text { w \% rok do roku } \\
\mathbf{2 0 1 2 - 2 0 1 3}\end{array}$ & $\begin{array}{c}\text { Wydatki na } \\
\text { obronność - jako } \\
\text { \% PKB w 2014 }\end{array}$ & $\begin{array}{c}\text { Wydatki na obron- } \\
\text { ność - w mld euro } \\
\mathbf{2 0 1 4}\end{array}$ & $\begin{array}{c}\text { Wydatki na obron- } \\
\text { ność - per capita } \\
\mathbf{2 0 1 4} \text { (euro) }\end{array}$ \\
\hline Austria & $-2,0 \%$ & $0,7 \%$ & 2,45 & 289 \\
\hline Belgia & $-3,8 \%$ & $1,03 \%$ & 3,81 & 341 \\
\hline Bułgaria & $8,8 \%$ & $1,5 \%$ & 0,58 & 80 \\
\hline Chorwacja & brak danych & $1,45 \%$ & 0,56 & 132 \\
\hline Cypr & $-10,3 \%$ & $1,76 \%$ & 0,31 & 280 \\
\hline Czechy & $-3,3 \%$ & $1,08 \%$ & 1,52 & 145 \\
\hline Dania & $\#$ & $\#$ & 3,44 & 809 \\
\hline Estonia & $6,3 \%$ & $1,96 \%$ & 0,38 & 290 \\
\hline
\end{tabular}

5 Pojawiają się nawet twierdzenia, $\mathrm{z}$ którymi trudno się nie zgodzić, iż „na obecnym poziomie nakładów na obronność narodowa suwerenność zanika, stając się cieniem samej siebie" (Coelmont, Mattelaer, 2013, s. 70). 
Polskie Studia Politologiczne

\begin{tabular}{|c|c|c|c|c|}
\hline Państwo & $\begin{array}{c}\text { Wydatki na obron- } \\
\text { ność - zmiana } \\
\text { w \% rok do roku } \\
2012-2013\end{array}$ & $\begin{array}{c}\text { Wydatki na } \\
\text { obronność - jako } \\
\text { \% PKB w } 2014\end{array}$ & $\begin{array}{l}\text { Wydatki na obron- } \\
\text { ność - w mld euro } \\
2014\end{array}$ & $\begin{array}{c}\text { Wydatki na obron- } \\
\text { ność - per capita } \\
2014 \text { (euro) }\end{array}$ \\
\hline Finlandia & $0,2 \%$ & $1,47 \%$ & 2,75 & 506 \\
\hline Francja & $0,7 \%$ & $1,91 \%$ & 43,07 & 652 \\
\hline Grecja & $-6,5 \%$ & $1,68 \%$ & 4,16 & 377 \\
\hline Hiszpania & $-12,3 \%$ & $0,93 \%$ & 10,34 & 222 \\
\hline Holandia & $-4,5 \%$ & $1,27 \%$ & 7,74 & 461 \\
\hline Irlandia & $-1,1 \%$ & $0,54 \%$ & 0,89 & 195 \\
\hline Litwa & $4,5 \%$ & $0,77 \%$ & 0,30 & 102 \\
\hline Luksemburg & $5,4 \%$ & $0,39 \%$ & 0,18 & 348 \\
\hline Łotwa & $6,5 \%$ & $0,91 \%$ & 0,22 & 112 \\
\hline Malta & $4,3 \%$ & $0,57 \%$ & 0,04 & 106 \\
\hline Niemcy & $4,0 \%$ & $1,23 \%$ & 32,40 & 402 \\
\hline Polska & $-0,5 \%$ & $1,73 \%$ & 7,78 & 202 \\
\hline Portugalia & $9,5 \%$ & $1,57 \%$ & 1,94 & 185 \\
\hline Rumunia & $12,9 \%$ & $1,3 \%$ & 2,01 & 101 \\
\hline Słowacja & $-8,2 \%$ & $1,01 \%$ & 0,76 & 141 \\
\hline Słowenia & $-9,7 \%$ & $1,08 \%$ & 0,35 & 171 \\
\hline Szwecja & $0,9 \%$ & $1,12 \%$ & 5,07 & 529 \\
\hline Węgry & $-11,4 \%$ & $0,93 \%$ & 0,75 & 77 \\
\hline $\begin{array}{c}\text { Wielka } \\
\text { Brytania }\end{array}$ & $-3,7 \%$ & $2,13 \%$ & 45,77 & 714 \\
\hline Włochy & $-2,5 \%$ & $1,29 \%$ & 20,59 & 344 \\
\hline $\begin{array}{c}\text { Średnia } \\
\text { UE-27 }\end{array}$ & $-0,9 \%$ & $1,45 \%$ & 7,15 & 297 \\
\hline
\end{tabular}

* niestety Eurostat nie dysponuje nowszymi danymi statystycznymi. Inne podmioty, które podejmują się gromadzenia podobnych danych, jak chociażby NATO, Bank Światowy, Sztokholmski Międzynarodowy Instytut Badań nad Pokojem (SIPRI), także mają szczątkowe jedynie statystyki, a ponadto w obliczeniach stosują inną metodologię czy walutę, stąd niemożliwe jest przedstawienie ich tutaj razem w zbiorczej tabeli.

\# Dania nie jest członkiem Europejskiej Agencji Obrony, stąd brak danych.

Źródło: Europejska Agencja Obrony. (2015). National Defence Data 2013 of the 27 EDA Member States, Bruksela, s. 5-8 i 16; Instytut Unii Europejskiej Studiów nad Bezpieczeństwem. (2015). Yearbook of European Security 2015, Paryż, s. 70-71. 
O zdolnościach wojskowych, tych posiadanych, ale i tych, które chciałoby się osiągnąć, nie należy dyskutować w oderwaniu od aktualnych wydarzeń na arenie międzynarodowej (Coelmont, Mattelaer, 2013). W przypadku zintegrowanej Europy wydarzenia mające miejsce w ciągu kilku ostatnich lat w jej bezpośrednim sąsiedztwie pozwalają wysnuć twierdzenie, że europejska obrona praktycznie nie istnieje i znajduje się w stanie krytycznym. A nadal pozwalamy sobie na to, i tu kolejna przeszkoda na drodze pogłębiania i racjonalizacji procesów integracyjnych, by niemal każde państwo członkowskie z osobna, w imię interesów narodowych, budowało własne systemy uzbrojenia i różnego typu sprzęt wojskowy. Nałożone na wydatki militarne ograniczenia budżetowe wyzwoliły, dodatkowo, we władzach państwowych tendencje protekcjonistyczne, mające za zadanie utrzymanie możliwości produkcyjnych krajowych przemysłów zbrojeniowych. Doszło już więc do takiego stanu, w którym w Europie mamy do czynienia z wielokrotnie większą (od 2 do 6 razy, w zależności od typu uzbrojenia ${ }^{6}$ ) liczbą projektów i otwartych linii produkcyjnych aniżeli ma to miejsce w USA (Briani, 2013). Utrzymywane są więc, sztucznie, zbędne linie produkcyjne, wytwarzane są, de facto, „zbędne technologie” (Liberti, 2011, s. 29), co prowadzi, w konsekwencji, przy zmniejszonych zamówieniach krajowych, do ostrej rywalizacji przedsiębiorstw zbrojeniowych na rynkach pozaeuropejskich i pogłębiania postaw uchylania się od współpracy (PE, 2015). Takie rozdrobnienie, fragmentacja, wskazywane jest, najczęściej, jako „pojedyncza najistotniejsza słabość europejskiego przemysłu zbrojeniowego" (Wiśniewski, 2012, s. 102).

Nie będzie przecież odkrywczym konstatacja, iż państwa europejskie mogłyby zyskać o wiele więcej, gdyby wydawały swoje pieniądze wspólnie, tworząc pewną wartość dodaną. Doskonałym na to przykładem są chociażby wspólne projekty naukowo-badawcze w zakresie uzbrojenia, pewna standaryzacja sprzętu pozostającego na wyposażeniu armii europejskich czy wreszcie wspólne systemy zamówień w tym zakresie. W kwestii standaryzacji Komisja Europejska zleciła już w 1999 roku, przeprowadzenie badania (tzw. Sussex Study), które potwierdziło, że takie kroki mogą przyczynić się, w zależności od typu uzbrojenia, do zmniejszenia kosztów produkcji nawet o 50\% (Fiott, 2014). O wspólnych zakupach sprzętu wojskowego mówi się z kolei, że „dla większości państw jest to, jeśli nie doskonała opcja, to przynajmniej akceptowalny kompromis między

6 Dla przykładu w 2013 roku USA posiadały 3 typy samolotów-tankowców (tankowanie w powietrzu) i miały na stanie 550 sztuk; państwa europejskie dysponowały 10 typami takich samolotów, a fizycznie użytkowały raptem 42 . 
brakiem możliwości krajowych w zakresie rozwijania programów zbrojeniowych a produktami dostępnymi już na rynku, najczęściej produkcji amerykańskiej" (Heuninckx, 2008, s. 145).

Wszystkie wskazane powyżej czynniki powodują postępującą erozję znaczenia i siły państw europejskich w świecie (Faleg, Giovannini, 2012). Podjęcie zaś przez państwa członkowskie wspólnych działań wymaga i będzie wymagać determinacji, politycznej woli, a nade wszystko dalekosiężnej wizji celu, do którego powinna Europa zmierzać. Konieczne będą też trudne i niepopularne politycznie decyzje, ponieważ „stawką jest zdolność UE (jako całości i jako poszczególnych państw - R.W.) do zagwarantowania sobie bezpieczeństwa" (Briani, 2013, s. 6).

\section{SZCZYT RADY EUROPEJSKIEJ W GRUDNIU 2013 ROKU}

Pierwszym symptomem świadczącym o istnieniu politycznej woli państw członkowskich UE i dostrzeganiu przez nie potrzeby dokonania pewnych przesunięć akcentów i przewartościowań w ramach polityki obronnej była chęć podjęcia dyskusji na ten temat. Preludium do rozmów na najwyższym szczeblu był przygotowany przez Komisję Europejską w lipcu 2013 roku komunikat $W$ kierunku bardziej konkurencyjnego i wydajnego sektora obronności i bezpieczeństwa (COM/2013/0542 final), w którym podkreślano m.in. znaczenie tego sektora dla wzrostu gospodarczego. Co więcej, przedstawiono w nim zarys pomysłów mających docelowo przyczynić się wyeliminowania problemów w wewnątrzunijnym handlu sprzętem wojskowym oraz wsparcia europejskich koncernów zbrojeniowych (O’Donnell, 2013).

Przez wiele lat jedynie mówiło się o tym, że należy przygotować specjalny szczyt przywódców integrujących się państw europejskich dotyczący zreformowania WPBiO, by stała się ona narzędziem efektywniejszym i skuteczniejszym. Wysoka Przedstawiciel Unii ds. Zagranicznych i Polityki Bezpieczeństwa Catherine Ashton, we współpracy z podległymi jej służbami i Europejską Agencją Obrony, przygotowała na to spotkanie specjalny raport wskazujący kluczowe problemy i wyzwania stojące przed WPBiO. Kontekst geopolityczny także nie pozostał bez wpływu na przebieg obrad (np. Ukraina, Syria). Podkreślono konieczność zapewnienia pokoju obywatelom UE, spokoju na jej granicach zewnętrznych, nade wszystko zaś wzmocnienia zdolności wojskowych UE oraz konieczność wzmocnienia konkurencyjności i innowacyjności europejskiego sektora technologicznego w zakresie uzbrojenia (Fiott, 2013). I choć oczekiwa- 
nia opinii publicznej i ekspertów były większe, wszak nie pokuszono się nawet o wskazanie oczekiwanej przyszłej militarnej roli UE jako aktora w sektorze bezpieczeństwa międzynarodowego, to jednak szczyt nie zakończył się kompletnym fiaskiem (Biscop, Coelmont, 2012; Blockmans, Faleg, 2015). Podjęto bowiem wówczas kilka decyzji technicznych ${ }^{7}$ acz je także należy uznać za niewielką kroplę w morzu potrzeb. Nakazano także Wysokiej Przedstawiciel rozpoczęcie prac analitycznych dotyczących zmian zachodzących w środowisku międzynarodowym i związanych $\mathrm{z}$ tym nowych wyzwań dla bezpieczeństwa UE, mających zaowocować w 2016 roku w postaci aktualizacji bądź przygotowania zupełnie nowej Europejskiej Strategii Bezpieczeństwa. Jak wskazuje bowiem Thierry Tardy, „tocząca się debata nie dotyczy już tego, czy UE jest podmiotem bezpieczeństwa, lecz jakim (podmiotem - R.W.) się ona stała i jak istotnym globalnie jest" (Tardy, 2015, s. 34).

\section{SZCZYT NATO W NEWPORT W 2014 ROKU}

Drugą przesłanką świadczącą o większym zrozumieniu integrującej się Europy dla kwestii obronności i nakładów na nią ponoszonych jako czynnika absolutnie koniecznego dla zwiększania bezpieczeństwa, zwłaszcza w świetle niestabilności Afryki Północnej, konfliktów na Bliskim Wschodzie oraz na Ukrainie, a także zamachów terrorystycznych w Paryżu, był konsensus przyjęty podczas szczytu NATO w Newport w 2014 roku. Sojusznicy zgodzili się wówczas nie tylko zaprzestać dalszego obniżania nakładów na obronność i łatania tym samym rosnących deficytów budżetowych, lecz przede wszystkim przystali na to, by każdy z nich osiągnął, docelowo, poziom nakładów na obronność równy $2 \%$ PKB rocznie. Co więcej, przyjęto także regułę, by minimum $20 \%$ z tych środków alokowano na zakup nowoczesnego sprzętu, uzbrojenia i spożytkowywano na badanie i rozwój technologii w tym zakresie. Oczywiście stać się to ma nie od razu, a w ciągu dekady, niemniej pierwsze dane spływające do siedziby Sojuszu z resortów obrony państw członkowskich są optymistyczne i pozwalają wierzyć, że tak się faktycznie stanie (de France, 2016; Fryc, 2015; SIPRI, 2015; Techau, 2015).

7 Europejska Agencja Obrony otrzymała wsparcie m.in. na realizację czterech programów: Zdalnie sterowane Systemy Lotnicze (Remotely Piloted Aircraft Systems), Tankowanie w powietrzu (Air-to-Air Refuelling), Komunikacja satelitarna (Satellite Communications) i Cyber Obrona (Cyber Defence) (EAO, 2014a). 
Koniecznie należy sobie uświadomić, że samo spełnienie przez sojuszników zobowiązań dotyczących poziomu nakładów budżetowych na obronność oraz ich struktury nie stanowi, samo w sobie, gwarancji bezpieczeństwa państw. Wystarczy bowiem, że trzeba będzie przeznaczyć większe środki na uposażenia wojskowych - a więc nakłady na wojsko wzrosną - co wcale nie przełoży się na zwiększanie zdolności operacyjnych, mobilności, wyszkolenia czy wyposażenia sił zbrojnych. Nie ma też przecież absolutnej pewności, że w razie wystąpienia takiej konieczności wszystkie państwa, zachowując proporcje, solidarnie wywiążą się z zobowiązania udzielenia pomocy.

Trzeba także pamiętać, by państwa koordynowały w ramach Sojuszu podejmowane przez siebie działania względem własnych sił zbrojnych. Kwestia ta również pojawiła się w Newport. Nie powinno bowiem dochodzić do sytuacji osłabiania sprawności Paktu przez nieskoordynowane redukcje poszczególnych rodzajów sił zbrojnych, jednostek czy typów uzbrojenia w kilku bądź kilkunastu państwach członkowskich jednocześnie. Efekt wizerunkowy tego typu zmian jest nie do przecenienia, bowiem już dziś europejska flanka Sojuszu postrzegana jest przez strony trzecie jako dalece nieskuteczna i niezaradna (np. operacja w Libii) (Mölling, 2012). Dalej, postulowane zmiany, w związku z niewystarczającymi budżetami obronnymi, takie jak chociażby zamiana rotacyjnej na stałą obecność sił NATO na jego wschodnich rubieżach, napotykają na silny opór niektórych państw. A tego typu kroki i decyzje, podawane do wiadomości publicznej, są pilnie śledzone przez państwa i inne podmioty żywo zainteresowane dalszym osłabianiem siły i znaczenia państw NATO i UE w świecie (Fryc, 2015).

\section{UWAGI PODSUMOWUJĄCE}

Jak stwierdził Stanisław Koziej, „Europa stoi przed poważnymi wyzwaniami politycznymi, gospodarczymi i społecznymi, z którymi musi sobie radzić. Podstawowym warunkiem skutecznego im sprostania jest bezpieczeństwo" (Koziej, 2011, s. 19. Podobnie: Emmerson, 2008; Karwat, 2011). Co zaskakujące to fakt, że wielu polityków i dyplomatów głęboko wierzy(ło), iż dobra lub bardzo dobra współpraca gospodarcza i handlowa państw trzecich z Europą automatycznie pociągnie za sobą stabilizację, pokój i postępowanie na arenie międzynarodowej zgodne z duchem europejskich wartości. Jeśli nawet nie od razu, to w dającej się przewidzieć perspektywie czasowej. Nic bardziej mylnego. Siła, militarna zwłaszcza, pozostaje w dalszym ciągu realną walutą, nie tylko w bezpośrednim sąsiedz- 
twie UE. Stąd też płynie jeden - jak się wydaje - wniosek: choć stale na znaczeniu zyskują zagrożenia niemilitarne (np. migracje) czy asymetryczne (np. terroryzm), to jednak państwa Starego Kontynentu nie powinny, ba - nie mogą zapominać o tradycyjnych źródłach zagrożeń, czego najbardziej aktualnym przykładem są konflikty na Ukrainie, w Syrii i w Iraku (Popowski, 2014) ${ }^{8}$. O ile bowiem NATO i USA potrafiły zareagować na te wydarzenia, to jednak UE ponownie tutaj zawiodła. Dlatego tak bardzo potrzeba dziś, celem uniknięcia poważnych problemów w przyszłości, drogowskazu w postaci nowej/zaktualizowanej strategii bezpieczeństwa Unii oraz konkretnych działań w postaci wyższych, racjonalnych, efektywnych i skoordynowanych nakładów na obronność i wspólne projekty zbrojeniowe państw Starego Kontynentu (Koziej, Formuszewicz, 2014) ${ }^{9}$. Potencjał zbrojeniowy jest, możliwości i sposobności nawiązania współpracy coraz częściej pojawiają się. Wydaje się, że jest także ku temu coraz większa wola polityczna. Miejmy więc nadzieję, że prędzej czy później, dla naszego własnego bezpieczeństwa, dystans dzielący potencjał obronny Europy od USA zacznie stopniowo topnieć.

\section{BibLIOGRAFIA:}

Barcikowska, A. (20130. Military capabilities and interoperability. W: E. Gross, A. Menon (red.), CSDP - between internal constraints and external challenges (s. 35). Paryż: Instytut UE Studiów nad Bezpieczeństwem.

Barry, Ch., Binnendijk, H. (2012). Widening Gaps in U.S. and European Defense Capabilities and Cooperation, Transatlantic Current, $n r$ 6, s. 1-5 i 10-12.

Bigo, D., Jeandesboz, J. (2010). The EU and the European Security Industry: Questioning the 'Public-Private Dialogue', INEX Policy Brief, nr 5, s. 1-7.

Biscop, S., Coelmont, J. (2012). Military Capabilities: From Pooling \& Sharing to a Permanent and Structured Approach, Egmont Security Policy Brief, nr 37, s. 1-4. Blockmans, S., Faleg, G. (2015). More Union in European Defence. Pobrane z: https:// www.ceps.eu/system/files/TFonEuropeanDefence.pdf, s. 3-5.

8 Roman Kuźniar (2014) pokusił się tu o niezwykle dosadną opinię: „W jak dużym stopniu potiomkinowską wsią stała się WPBiO, można było się przekonać w kontekście kryzysu na Ukrainie, a konkretnie agresji Rosji na Ukrainę. Ani przez moment to [...] wydarzenie nie zostało potraktowane przez UE jako problem bezpieczeństwa i obrony" (s. 43).

9 Pojawiają się jednak i głosy nawołujące do dalszych i jeszcze głębszych cięć wydatków na obronność, traktujące takie zachowania jako pozytywne (Slijper, 2013). 
Briani, V. (2013). Armaments Duplication in Europe: A quantitative assessment, CEPS Policy Brief, $n$ r 297, s. 3-4.

Coelmont, J., Mattelaer, A. (2013). Capability Development: The Times They Are a-Changin. W: S. Biscop, D. Fiott (red.), The State of Defence in Europe: State of Emergency?, Bruksela: Egmont Institute, s. 70.

de France, O. (2016). Defence spending in Europe in 2016. W: A. Marrone, O. de France, D. Fattibene (red.), Defence Budgets and Cooperation in Europe: Developments, Trends and Drivers (s. 8-19). Rzym: Instytut Spraw Międzynarodowych.

DeVore, M., Eisenecker, S. (2010). The Three Ages of Armaments Collaboration: Determinants of Organizational Success and Failure. Pobrane z: http://www.eisa-net. org/be-bruga/eisa/files/events/stockholm/The\%20Three\%20Ages\%20of\%20\%20 Collaboration\%20SGIR.pdf, s. 12.

Emerson, M. (2008). The Struggle for a Civilised Wider European Order. Elements for European Security Strategy, CEPS Working Document, nr 307, s. 26.

Europejska Agencja Obrony. (2012). Europe and United States Defence Expenditure in 2010, Bruksela, s. 4 i 13.

Europejska Agencja Obrony. (2013). Europe and United States Defence Expenditures 2011, Bruksela, s. 4 i 13.

Europejska Agencja Obrony. (2014a). Annual Report 2013, Bruksela, s. 8-15.

Europejska Agencja Obrony. (2014b). National Defence Data 2012 of the EDA participating Member States, Bruksela, s. 13 i 19.

Europejska Agencja Obrony. (2015). National Defence Data 2013 of the 27 EDA Member States, Bruksela, s. 5-8 i 16.

Faleg, G. (2013). The Governance Gap in European Security and Defence, CEPS Policy Brief, nr 310, s. 6-7.

Faleg, G., Giovannini, A. (2012). The EU between Pooling \& Sharing and Smart Defence. Making a virtue of necessity, CEPS Commentary, s. 3 i 22.

Fiott, D. (2013). The European Defence Technological and Industrial Base: Five Suggestions. W: S. Biscop, D. Fiott (red.), The State of Defence in Europe: State of Emergency? (s. 73). Bruksela: Egmont Institute.

Fiott, D. (2014). One size to fit all? Setting standards for European defence, EU ISS Brief Issue, $n$ r 13, s. 1.

Frontini, A. (2015). Federalist rhetoric or political tactics? The what, where, who, when and why of Juncker's call for a common European army, EPC Commentary, s. 2.

Fryc, M. (2015). Strategiczne konsekwencje cięć w wydatkach obronnych państw członkowskich NATO, Bezpieczeństwo Narodowe, nr 35, s. 52-60.

Gałganek, A. (2011). Maszyny wojny. Technologia militarna w 'społecznej' historii stosunków międzynarodowych, Przegląd Strategiczny, nr 2, s. 19.

Heuninckx, B. (2008). A Primer to Collaborative Defence Procurement in Europe: Troubles, Achievements and Prospects, Public Procurement Law Review, vol. 17 (nr 3), s. 145.

Howorth, J. (2000). European Integration and Defence: the Ultimate Challenge?, Chaillot Papers, nr 43, s. 1-97. 
Huxham, Q., Rempling, D.H.C. (2013). The Start-Up Fund - An Elegant Treaty Mechanism for Sustaining Defence Capabilities, Egmont Security Policy Brief, nr 48, s. 2.

Instytut Unii Europejskiej Studiów nad Bezpieczeństwem. (2015). Yearbook of European Security 2015, Paryż, s. 70-71.

Karwat, J. (2011). Problemy bezpieczeństwa Unii Europejskiej, Przegląd Strategiczny, nr 1, s. 75.

Koziej, S. (2011). Potrzeba nowelizacji strategii bezpieczeństwa Unii Europejskiej, Bezpieczeństwo Narodowe, nr 20, s. 19.

Koziej, S., Formuszewicz, R. (2014). O potrzebie nowej strategii bezpieczeństwa Unii Europejskiej, Bezpieczeństwo Narodowe, nr 32, s. 30.

Kuźniar, R. (2014). Wzlot i upadek Europejskiej Polityki Bezpieczeństwa i Obrony, Bezpieczeństwo Narodowe, nr 32, s. 43.

Liberti, F. (2011). Defence spending in Europe: Can we do better without spending more?, Notre Europe Policy Paper, nr 46, s. 29.

Manners, I. (2006). Normative power Europe reconsidered: beyond the crossroads, Journal of European Public Policy, vol. 13 (nr 2), s. 182-199.

Margaras, V. (2010). Common Security and Defence Policy and the Lisbon Treaty Fudge: no common strategic culture, no major progress, EPIN Working Paper, $n r$ 28, s. 7-8.

Mölling, Ch. (2012). Trends within the European Union. W: C.M. O’Donnell (red.), The Implications of Military Spending Cuts for NATO's Largest Members (s. 6). Waszyngton: Brookings.

NATO. (2016). The Secretary General's Annual Report 2015, Bruksela, s. 26.

O’Donnell, C.M. (2013). Industry. W: E. Gross, A. Menon (red.), CSDP - between internal constraints and external challenges (s. 25-20). Paryż: Instytut UE Studiów nad Bezpieczeństwem.

Parlament Europejski (PE). (2015). The extra EU defence exports'effects on European armaments cooperation. Pobrane z: http://www.europarl.europa.eu/RegData/etudes/ STUD/2015/549043/EXPO_STU\%282015\%29549043_EN.pdf, s. 7.

Popowski, M. (2014). Transatlantyckie struktury bezpieczeństwa w obliczu kryzysu ukraińskiego, Bezpieczeństwo Narodowe, nr 32, s. 104.

Przedstawicielstwo Amerykańskiej Izby Handlowej przy Unii Europejskiej (AMCHAM). Security and Defence. Together for European growth. Pobrane z: http://www.amchameu.eu/sites/default/files/publications/files/securitydefence.pdf, s. 4-9.

SIPRI. (2015). Military spending in Europe in the wake of the Ukraine crisis. Pobrane z: http://www.sipri.org/media/website-photos/milex-media-backgrounder-2015, s. $7-9$.

Slijper, F. (2013). Guns, debt and corruption. Military spending and the EU crisis. Pobrane z: https://www.tni.org/files/download/eu_milspending_crisis.pdf, s. 1-20.

Smith, K. (2000). The End of Civilian Power EU: A Welcome Demise or a Cause for Concern?, The International Spectator, vol. 35 ( $\mathrm{nr} 2)$, s. 11-28.

Tardy, T. (2015). CSDP in action. What contribution to international security?, Chaillot Paper, nr 134, s. 34. 
Techau, J. (2015). The Politics of 2 Percent. NATO and Security Vacuum in Europe. Pobrane z: http://carnegieendowment.org/files/CP_252_Techau_NATO_Final. pdf, s. 3-5.

Wiśniewski, R. (2012). Defence industry in the European Union - challenges and opportunities in times of economic crisis, Przeglad Strategiczny, $n r$ 2, s. 96-98. 